\title{
A COMPARISON OF THE EFFECTS OF EXTRACTION AND NONEXTRACTION ORTHODONTIC TREATMENTS ON CEPHALOMETRIC PARAMETERS AND ARCH WIDTHS
}

\begin{abstract}
Objectives: To compare the effects of two different treatment approaches on cephalometric measurements and arch widths.
\end{abstract}

Materials and Methods: The retrospective study evaluated pre- and post-treatment cephalometric radiograms and dental models of 45 patients with Class I malocclusions and moderate-severe dental tooth size arch length discrepancies that underwent extraction or nonextraction treatment between 2015 and 2020. Group I ( $n=22$ [9 female, 13 male]; mean age, $18.0 \pm 1.68$ years) was treated with the Damon $\mathrm{Q}$ bracket system and Group II ( $\mathrm{n}=23$ [11 female, 12 male]; mean age, $17.9 \pm 1.34$ years) was treated with the conventional MBT bracket system. Pre- and post-treatment lateral cephalometric radiograms were obtained and arch widths were measured for each subject. Paired samples t-test was used to evaluate the treatment changes within each group. To compare the changes between groups, independent samples t-test was performed.

Results: No significant change was detected in the sagittal and vertical skeletal parameters in both groups $(p>0.05)$. The upper and lower incisors proclined significantly in Group I $(p<0.01)$ and the mandibular incisors retroclined significantly in Group II $(p<0.05)$. The lips protruded significantly and the upper lip thickness decreased significantly in Group I $(p<0.01)$, whereas no significant difference was observed in Group II ( $p>0.05)$. All the transversal dimensions increased significantly in Group I $(p<0.01)$, while only the intermolar distances decreased significantly in Group II $(p<0.01)$.

Conclusions: Both treatment methods provided significantly different outcomes with regard to soft tissue parameters and arch widths.

Key words: Extraction, nonextraction, orthodontics.
*Mehmet Ali Yavan ${ }^{1}$

Sumeyye Guler ${ }^{1}$

Merve Nur Eglenen ${ }^{2}$

Mehmet Nezir Karaca ${ }^{3}$

ORCID IDs of the authors:

M.A.Y. 0000-0002-2162-060X

S.G. $\quad 0000-0002-0572-015 \mathrm{X}$

M.N.E. $\quad$ 0000-0001-7688-0858

M.N.K. 0000-0001-8612-0094
Received : : 18.10 .2020

Accepted $\quad: 23.12 .2020$

\footnotetext{
How to Cite: Yavan MA, Güler S, Egeden MN, Karaca MN. A Comparison of the Effects of Extraction and Nonextraction Orthodontic Treatments on Cephalometric Parameters and Arch Widths. Cumhuriyet Dent J 2021;24:1:47-56.

*Corresponding Author:

Department of Orthodontics, Faculty of Dentistry, Adıyaman University, Adiyaman, Turkey. Postal code 02240 Phone: +905435638363 


\section{INTRODUCTION}

The tooth size arch length discrepancies are commonly encountered malocclusion in dental practice. ${ }^{1,2}$ This problem can be treated by two approaches during permanent dentition: extraction and nonextraction treatment. Over the last century, however, the decision to extract permanent teeth in cases with tooth size arch length discrepancies have remained a controversial issue due to aesthetic concerns. ${ }^{3}$

Extraction of premolar teeth for orthodontic reasons is widely performed to achieve ideal levelling of incisor teeth and to ensure a highstandard orthodontic finishing and long-term stability. ${ }^{4}$ However, nonextraction treatment has become highly popular particularly in the presence of condylar displacement, dark buccal corridors, concave profile, and suboptimal mandibular growth concerns. ${ }^{5,6}$

Nonextraction treatment eliminates the irregularities via transversal expansion of arches and proclination of incisors. ${ }^{7,8}$ The Damon selfligating bracket system (Ormco, Glendora, California, USA) is a nonextraction treatment that has been shown to be superior to conventional bracket systems due to its production of low force and low friction. Additionally, this system has also been shown to provide several advantages including increased patient comfort during treatment, fewer visits to the orthodontist, shorter treatment times, less need for extraction, and better results in terms of both occlusal and facial aesthetics. ${ }^{9-11}$

Studies comparing the effects of extraction and nonextraction treatments on the arch widths, contrary to popular belief, have revealed that premolar extraction methods lead to no significant decrease in the intercanine distance compared to nonextraction methods. ${ }^{6}$ Moreover, it has also been shown that the Damon bracket system can achieve a significant expansion in buccal segments in nonextraction treatments. ${ }^{8,12,13}$ On the other hand, while some of the studies comparing the Damon bracket system and conventional bracket systems in patients undergoing nonextraction treatment found significant differences in intermolar distances ${ }^{8,14,15}$, some others found no significant differences between the bracket systems with regard to intermolar distance. ${ }^{13-16}$

To our knowledge, there has been no study comparing the cephalometric and arch width parameters in patients treated with a nonextraction approach using the Damon bracket system and with an extraction approach using the MBT system, particularly in borderline cases. The retrospective study was designed to compare cephalometric measurements in borderline patients with Class I malocclusions and moderate-severe tooth size arch length discrepancies who were treated with these two treatment approaches and to analyze the effects of these measurements on dental arches. The null hypothesis is that there are significant differences between two approaches with regard to their cephalometric and dental arc measurements.

\section{MATERIALS AND METHODS}

The retrospective study evaluated pre- and posttreatment cephalometric radiograms and dental models of patients that underwent extraction or nonextraction treatment in Adiyaman University School of Dentistry Orthodontics Department between 2015 and 2020. An approval was obtained from Adiyaman University Noninterventional Clinical Research Ethics Committee (Approval No: 2019/8-6).

Power analysis was performed using GPOWER statistical software (Ver. 3.1 Franz Faul, Universität Kiel, Kiel, Germany), in which the minimum number of samples was determined as 34 based on an alpha level of 0.05 , a power of 0.80 , and an effect size of 0.87 considering the mean PAR score after treatment was $3.5 \pm 3.19$ in four first premolar extraction group and $1.4 \pm 1.14$ in the nonextraction group derived from İleri et al. ${ }^{17}$ To increase the power of the study, a total of 45 patients were included in the analysis.

To create a comparable dataset, the treatment records of each patient were re-examined to identify treatment procedures and only those treated with the same procedure were analyzed. The pretreatment inclusion and selection criteria for the nonextraction group were as follows; skeletal Class I malocclusion (ANB [A point, nasion, B point], $0-5^{\circ}$ ), angle Class I malocclusion, age in the permanent dentition period, 
a minimum of 5-mm maxillary and mandibular tooth size arch length discrepancies according to HayesNance analysis, absence of systemic diseases, absence of missing permanent teeth or congenitally absent teeth, absence of prior orthodontic treatment, and not using any additional appliance (miniscrew, Herbst appliance, lip bumper appliance, headgear, or distalization device), during the treatment, using the Damon Q bracket system (Ormco, California, USA) (0.022-inch bracket slot size) and bonding brackets in the upper and lower arches to the level of seventh teeth (Figure 1), finishing the treatment by performing dental levelling and alignment with $0.19 " \mathrm{x} 0.25$ " stainless steel archwires.

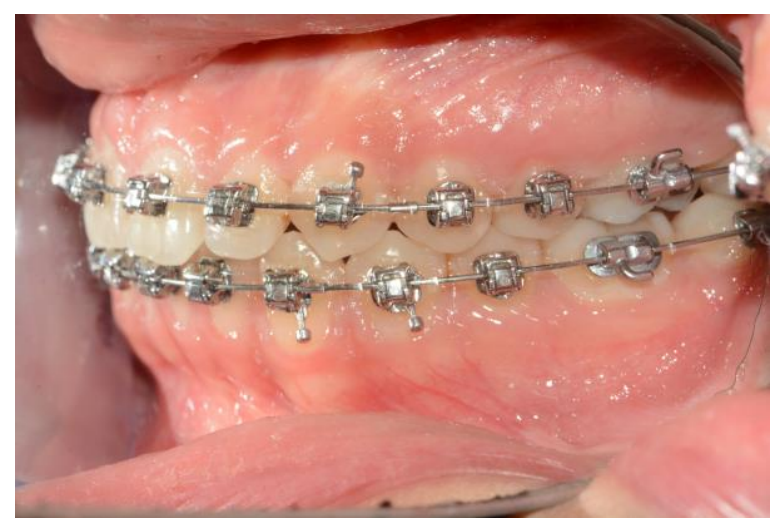

Figure 1. Nonextraction treatment with the Damon bracket system.

The nonextraction group consisted of 22 patients ( 9 female, 13 male; mean age, $18.0 \pm 1.68$ years).

The patients who fulfilled the following pretreatment inclusion and selection criteria were included in the extraction group; skeletal Class I malocclusion, angle Class I malocclusion, age in the permanent dentition period, a minimum of 5$\mathrm{mm}$ maxillary and mandibular tooth size arch length discrepancies according to Hayes-Nance analysis, absence of systemic diseases, absence of missing permanent teeth or congenitally absent teeth, absence of prior orthodontic treatment, and not using any additional appliance, during the treatment, extraction of the four first premolars and applying the MBT bracket system (Mini Master Series; American Orthodontics, Sheboygan, WI, USA) and bonding brackets in the upper and lower arches to the level of seventh teeth (Figure 2), achieving the dental levelling and alignment with $0.014 ", 0.016 ", 0.016 " x 0.022 "$ and $0.017 " x 0.022^{\prime \prime}$ Nickel titanium archwires, performing the canine distalization with moderate anchorage using 0.17"x0.22" stainless steel archwires, and finalizing the treatment by applying the finishing procedures after performing incisor consolidation. The extraction group consisted of 23 patients (11 female, 12 male; mean age, $17.9 \pm 1.34$ years).

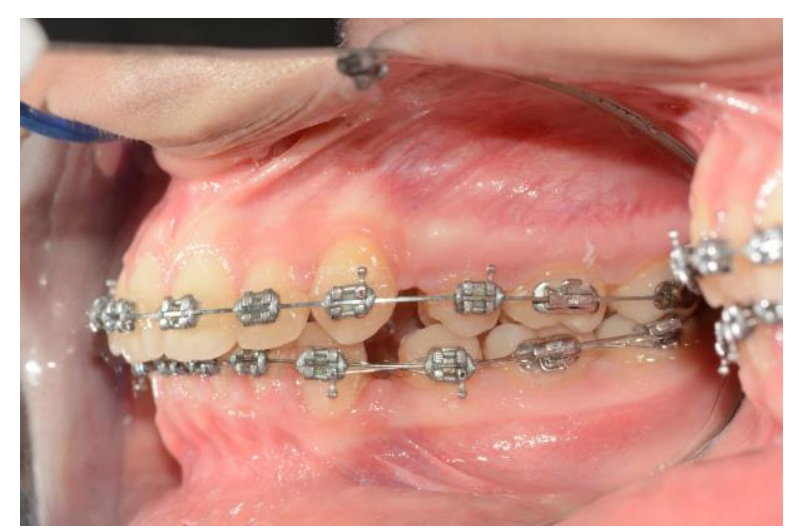

Figure 2. Four premolar extraction with the MBT bracket system.

Cephalometric radiograms along with extraand intra-oral images and plaster models were obtained both before (T1) and after the treatment (T2) by the same operator using the same cephalostat. Digital lateral cephalometric radiograms were obtained by the same operator using a Planmeca EC Proline PM 2002 Panoramic Dental X-ray Unit. The exposure values were set at $68-74 \mathrm{kV}, 5 \mathrm{~mA}$, and with an exposure time of 0.5 s. The receptor-source distance was fixed at 150 $\mathrm{cm}$. The rate of radiographic magnification was adjusted to 1.1 and all the digital cephalometric radiograms were obtained in a standing position with the teeth in centric occlusion and the subject's head positioned with Frankfurt's horizontal plane parallel to the ground, with the cephalostat ear-rods adjusted to hold the head in natural head position.

All the scanned images were processed by the same operator using Dolphin Imaging Version 10.5 (Dolphin Imaging, Chatsworth, California, USA) (Figure 3). 


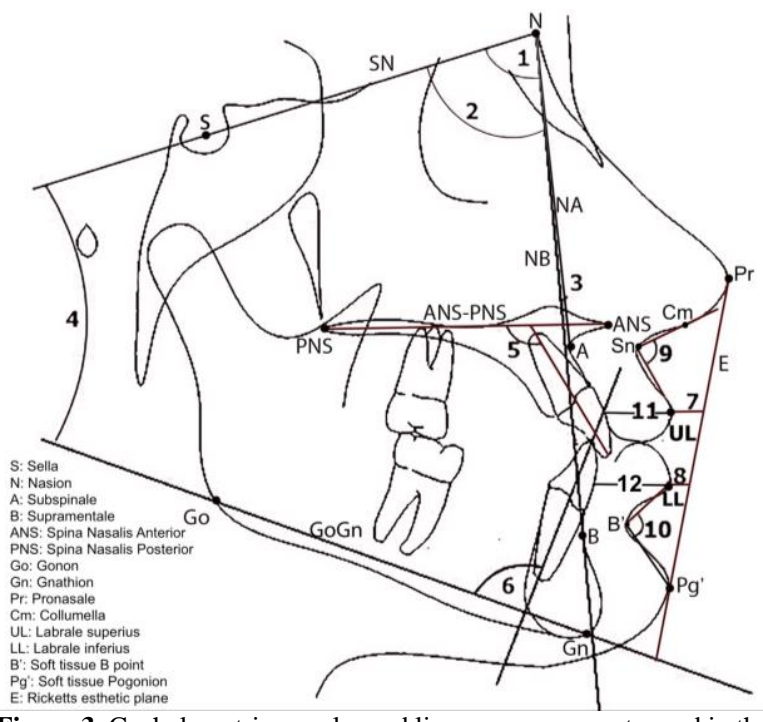

Figure 3. Cephalometric angular and linear measurements used in the study. $1 . \mathrm{SNA}^{\circ}$, angle formed by $\mathrm{S}-\mathrm{N}$ and $\mathrm{N}$-A planes; 2 . $\mathrm{SNB}^{\circ}$, angle formed by $\mathrm{S}-\mathrm{N}$ and $\mathrm{N}-\mathrm{B}$ planes; 3 . $\mathrm{ANB}^{\circ}$, angle formed by $\mathrm{N}-\mathrm{A}$ and $\mathrm{N}-\mathrm{B}$ planes; 4 . SN/GoGn ${ }^{\circ}$, angle formed by S-N and Go-Gn planes; 5. $\mathrm{U} 1 / \mathrm{PP}\left({ }^{\circ}\right)$, angle formed by U1 plane and ANS-PNS plane; 6. IMPA $\left({ }^{\circ}\right)$, angle formed by L1 plane and Go-Gn plane; UL-E $(\mathrm{mm})$, the distance between UL point and Pr-Pg' (E) plane; LL-E (mm), the distance between LL point and Pr-Pg' (E) plane; 9. Nasolabial angle, angle formed by $\mathrm{Cm}-\mathrm{Sn}$ and $\mathrm{Sn}-\mathrm{UL}$ planes; 10 . Mentolabial angle, angle formed by LL-B' and B'-Pg' planes; 11. UL thickness, the distance between the most facial point of the maxillary incisor and UL point and 12. LL thickness, the distance between the most facial point of the mandibular incisor and LL point.

Maxillary and mandibular tooth size arch length discrepancies were assessed on pretreatment dental casts using Hayes-Nance analysis. Crowding was categorized according to the Little's ${ }^{18}$ irregularity index [ideal alignment (0-0.9 mm), minimal (1-3.9 $\mathrm{mm})$, moderate $(4-6.9 \mathrm{~mm})$, severe $(7-9.9 \mathrm{~mm})$, extreme (more than $10 \mathrm{~mm}$ )]. Measurements of pre- and post-treatment dental models were performed by the same operator using a digital caliper (Mitutoyo, Tokyo, Japan). Additionally, intercanine and intermolar width were also measured to assess the transversal changes induced by the treatment (Figure 4).

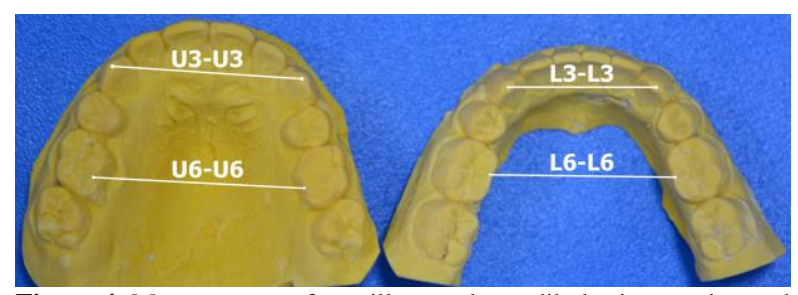

Figure 4. Measurement of maxillary and mandibular intercanine and intermolar distances on dental casts. U3-U3: the distance between the tips of the left and right upper canines; U6-U6: the distance between the most supero-palatal points of distolingual grooves of the left and right upper first molars; L3-L3: the distance between the tips of the left and right lower canines; L6-L6: the distance between the most supero-lingual points of lingual grooves of the left and right lower first molars.
Three weeks after the first measurements, 20 randomly selected cephalometric radiograms were redrawn and the model measurements were repeated to assess interrater reliability. In these measurements, the reliability coefficient was close to 1.00 (range, $0.92-0.99$ ).

\section{Statistical analysis}

Data were analyzed using SPSS 22.0 (IBM Corp. released 2013. IBM SPSS Statistics for Windows, Version 22.0, Armonk, NY: IBM Corp.). Descriptives were expressed as mean \pm standard deviation (SD). Normal distribution of data was determined using Kolmogorov-Smirnov test. Two independent variables with normal distribution were compared using Paired-Samples $t$-test and variables nonnormal distribution were compared using Mann-Whiney U test. Interrater reliability was assessed using Intraclass Correlation Coefficient (ICC). A $p$ value of $<0.05$ was considered significant.

\section{RESULTS}

Mean pretreatment maxillary tooth size arch length discrepancies were $7.70 \pm 0.61 \mathrm{~mm}$ in the extraction group and $6.80 \pm 0.34 \mathrm{~mm}$ in the nonextraction group. In contrast, mean pretreatment mandibular tooth size arch length discrepancies were $7.30 \pm 1.1 \mathrm{~mm}$ in the extraction group and $5.70 \pm 0.36 \mathrm{~mm}$ in the nonextraction group. No significant difference was found between the two groups with regard to pretreatment tooth size arch length discrepancy values $(p>0.05)$.

Table 1 presents the comparison of baseline cephalometric measurements in both groups. 
Table 1. Baseline descriptives and comparison of differences between the groups.

\begin{tabular}{|c|c|c|c|c|c|}
\hline & \multicolumn{2}{|c|}{ Extraction } & \multicolumn{2}{|c|}{ Nonextraction } & \multirow{2}{*}{ Overall $\mathrm{P}$ value } \\
\hline & Mean & SD & Mean & $\mathrm{SD}$ & \\
\hline Age (years) & 17.90 & 1.34 & 18.00 & 1.68 & 0.187 \\
\hline \multicolumn{6}{|c|}{ Skeletal cephalometric parameters } \\
\hline SNA $\left({ }^{\circ}\right)$ & 79.80 & 0.72 & 82.85 & 0.65 & $0.019 *$ \\
\hline $\mathrm{SNB}\left({ }^{\circ}\right)$ & 75.80 & 0.71 & 80.05 & 0.61 & $0.001 * * *$ \\
\hline $\mathrm{ANB}\left({ }^{\circ}\right)$ & 4.40 & 0.46 & 2.65 & 0.44 & $0.040 *$ \\
\hline $\mathrm{SN} / \mathrm{GoGn}\left({ }^{\circ}\right)$ & 38.00 & 1.21 & 32.80 & 1.19 & $0.002 * *$ \\
\hline \multicolumn{6}{|c|}{ Dental cephalometric parameters } \\
\hline $\mathrm{U} 1 / \mathrm{PP}\left({ }^{\circ}\right)$ & 109.30 & 4.98 & 111.40 & 1.43 & 0.674 \\
\hline $\operatorname{IMPA}\left({ }^{\circ}\right)$ & 89.5 & 1.43 & 83.55 & 1.48 & 0.153 \\
\hline \multicolumn{6}{|c|}{ Soft tissue cephalometric parameters } \\
\hline $\mathrm{UL}-\mathrm{E}(\mathrm{mm})$ & -1.40 & 0.48 & -3.30 & 0.40 & $0.035^{*}$ \\
\hline LL-E (mm) & -1.10 & 0.51 & -1.40 & 0.36 & $0.006^{* *}$ \\
\hline Nasolabial angle & 111.40 & 1.23 & 104.80 & 3.74 & $0.004 * *$ \\
\hline Mentolabial angle & 138.00 & 2.13 & 127.50 & 2.03 & $0.006 * *$ \\
\hline UL thickness & 10.60 & 0.41 & 12.50 & 0.45 & $0.004 * *$ \\
\hline LL thickness & 10.30 & 0.34 & 12.05 & 0.32 & $0.001 * * *$ \\
\hline \multicolumn{6}{|c|}{ Dental cast parameters } \\
\hline Overjet $(\mathrm{mm})$ & 3.50 & 0.38 & 3.50 & 0.43 & 0.699 \\
\hline Overbite (mm) & 2.50 & 0.32 & 3.10 & 0.42 & 0.202 \\
\hline U3-U3 (mm) & 33.50 & 0.57 & 34.7 & 0.64 & 0.420 \\
\hline U6-U6 (mm) & 43.00 & 0.50 & 46.2 & 0.64 & $0.001 * * *$ \\
\hline L3-L3(mm) & 25.50 & 0.37 & 25.8 & 0.51 & 0.892 \\
\hline L6-L6 (mm) & 38.4 & 0.47 & 41.05 & 0.60 & $0.005 * *$ \\
\hline Maxillary TSALD & -7.70 & 0.61 & -6.80 & 0.34 & 0.187 \\
\hline Mandibular TSALD & -7.30 & 1.01 & -5.70 & 0.36 & 0.382 \\
\hline
\end{tabular}

P: test result, SD: Standard deviation, mm: millimeter, TSASD: tooth size arch length discrepancies, ${ }^{*}: \mathrm{P}<0.05,{ }^{*} * \mathrm{P}<0.01$, ***: $\mathrm{P}<0.01$.

A significant difference was found between the two groups with regard to skeletal and soft tissue measurements $(p<0.05$ for both), while no significant difference was observed with regard to dental measurements $(p>0.05)$. Moreover, a significant difference was found between the two groups with regard to maxillary and mandibular intercanine measurements ( $p<0.05$ for both), whereas no significant difference was observed in terms of interdental measurements $(p>0.05)$.

Table 2 presents pre- and post-treatment cephalometric measurements and their changes in both groups.

Table 2. Descriptive values and comparison of variables at pretreatment and posttreatment periods.

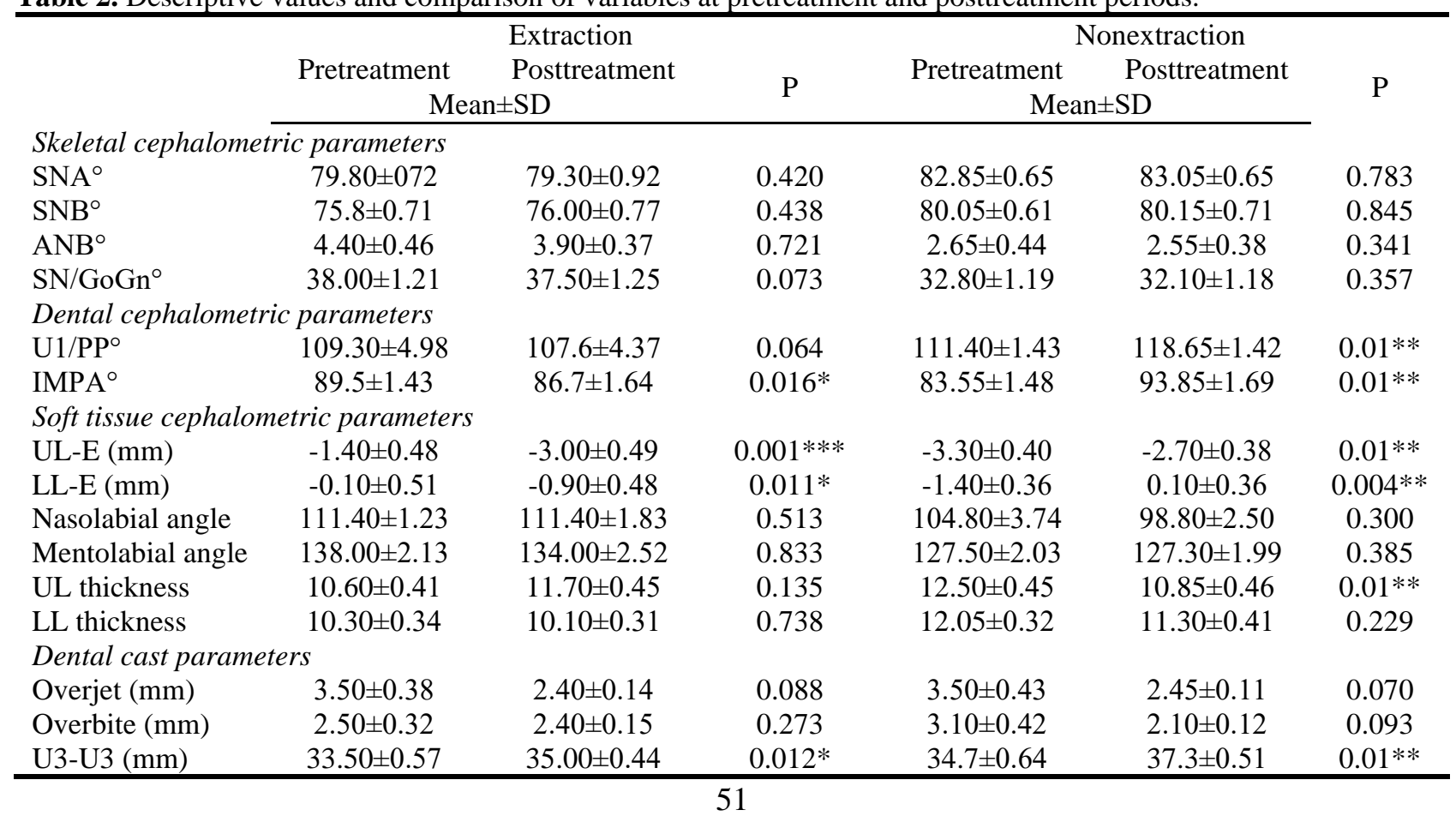




\begin{tabular}{lcccccc}
\hline U6-U6 (mm) & $43.00 \pm 0.50$ & $41.9 \pm 0.33$ & $0.001 * * *$ & $46.2 \pm 0.64$ & $48.0 \pm 0.59$ & $0.01 * *$ \\
L3-L3 (mm) & $25.50 \pm 0.37$ & $26.90 \pm 0.27$ & 0.095 & $25.8 \pm 0.51$ & $28.2 . \pm 0.41$ & $0.01 * *$ \\
L6-L6 (mm) & $38.4 \pm 0.47$ & $37.3 \pm 0.54$ & $0.009 * *$ & $41.05 \pm 0.60$ & $42.10 \pm 0.43$ & $0.01 * *$ \\
\hline P:
\end{tabular}

P: test result, SD: Standard deviation, mm: millimeter, *: $\mathrm{P}<0.05$, **: $\mathrm{P}<0.01$; ***: $\mathrm{P}<0.001$.

In the group treated with Damon Q system, no significant change was observed between pre- and post-treatment skeletal measurements $(p>0.05)$. The proclination of upper and lower incisors was statistically significant ( $p<0.05$ for both), while the reduction in the overjet and overbite was statistically insignificant $(p>0.05)$. On the other hand, the lower and upper lips significantly moved anteriorly $(p<0.01)$, no significant change occurred in nasolabial and mentolabial angles $(p>0.05)$, the upper lip thickness decreased significantly $(p<0.01)$, and no significant change occurred in the lower lip thickness ( $p>0.05$ ). Moreover, a significant increase was observed in interdental distances in both maxillary and mandibular molars ( $p<0.01$ for both).

In the group treated with the MBT bracket system with four premolar extraction, no significant change was observed between pre- and post-treatment skeletal measurements $(p>0.05)$.
Although the retroclination of the lower incisors was statistically significant $(p<0.05)$, no significant change was observed in the upper incisor angles $(p>0.05)$. Similarly, no significant change was observed in overjet and overbite ( $p>0.05$ for both). Both the lower and upper lips significantly moved posteriorly ( $p<0.05$ for both), while no significant change was detected in the nasolabial and mentolabial angles and in the lower and upper lip thickness ( $p>0.05$ for all). In model measurements, the maxillary intercanine distance increased significantly $(p<0.05)$, the maxillary and mandibular intermolar distances decreased significantly $(p<0.05)$, and no significant change was observed in the mandibular intercanine distance $(p>0.05)$.

Table 3 presents the changes detected in both groups.

Table 3. Treatment changes descriptive statistics of parameters and significance values between groups.

\begin{tabular}{|c|c|c|c|c|c|}
\hline & \multicolumn{2}{|c|}{ Extraction } & \multicolumn{2}{|c|}{ Nonextraction } & \multirow{2}{*}{$P$ value } \\
\hline & Mean & SD & Mean & SD & \\
\hline \multicolumn{6}{|c|}{ Skeletal cephalometric parameters } \\
\hline SNA $^{\circ}$ & 0.60 & 0.64 & 0.50 & 0.54 & 0.685 \\
\hline $\mathrm{SNB}^{\circ}$ & 2.00 & 0.75 & 2.00 & 0.75 & 0.460 \\
\hline $\mathrm{ANB}^{\circ}$ & -0.30 & 0.44 & 0.15 & 0.29 & 0.733 \\
\hline $\mathrm{SN} / \mathrm{GoGn}^{\circ}$ & -2.50 & 0.65 & -0.60 & 0.45 & 0.666 \\
\hline \multicolumn{6}{|c|}{ Dental cephalometric parameters } \\
\hline $\mathrm{U} 1 / \mathrm{PP}^{\circ}$ & -0.10 & 6.63 & 6.80 & 0.37 & $0.001 * * *$ \\
\hline $\operatorname{IMPA}^{\circ}$ & -1.90 & 1.15 & 5.75 & 1.30 & $0.001 * * *$ \\
\hline \multicolumn{6}{|c|}{ Soft tissue cephalometric parameters } \\
\hline $\mathrm{UL}-\mathrm{E}(\mathrm{mm})$ & -1.80 & 0.44 & 1.00 & 0.21 & $0.001 * * *$ \\
\hline LL-E (mm) & -1.80 & 0.56 & 1.10 & 0.25 & $0.001 * * *$ \\
\hline Nasolabial angle & -1.00 & 2.66 & -6.45 & -4.16 & $0.001 * * *$ \\
\hline Mentolabial angle & 2.00 & 2.09 & -2.50 & 2.00 & 0.725 \\
\hline UL thickness & 0.40 & 0.87 & -1.40 & 0.19 & $0.001 * * *$ \\
\hline LL thickness & 0.20 & 0.34 & -0.55 & 0.45 & 0.224 \\
\hline \multicolumn{6}{|c|}{ Dental cast parameters } \\
\hline Overjet (mm) & -1.10 & 0.44 & -0.80 & 0.40 & 0.856 \\
\hline Overbite (mm) & -0.30 & 0.46 & -0.55 & 0.38 & 0.053 \\
\hline U3-U3 (mm) & 1.8 & 0.62 & 2.25 & 0.41 & 0.666 \\
\hline U6-U6 (mm) & -0.80 & 0.60 & 1.60 & 0.69 & $0.001 * * *$ \\
\hline L3-L3 (mm) & 1.60 & 0.69 & 2.20 & 0.32 & $0.012 *$ \\
\hline L6-L6 (mm) & 0.00 & 0.55 & 1.05 & 0.35 & $0.001 * * *$ \\
\hline
\end{tabular}

P: test result, SD: Standard deviation, $\mathrm{mm}$ : millimeter, *: $\mathrm{P}<0.05$, **: $\mathrm{P}<0.01$, ***: $\mathrm{P}<0.01$.

No significant difference was found between the two groups with regard to the changes in skeletal measurements $(p>0.05)$. A significant difference was found with regard to the changes in the lower and upper incisor angles $(p<0.001)$ while no significant change was found with regard to the changes in overjet and overbite $(p>0.05)$. A significant difference was found between the two 
groups with regard to the changes in upper and lower lip position, nasolabial angle, and upper lip thickness $(p<0.05$ for all), whereas no significant difference was observed with regard to the changes in mentolabial angle and lower lip thickness ( $p>0.05$ for both). In model measurements, no significant difference was found between the two groups with regard to the maxillary intercanine distance ( $p>0.05$ ), while significant difference was found in terms of the changes in other maxillary and mandibular interdental distances $(p<0.05)$.

\section{DISCUSSION}

Tweed ${ }^{19}$ claimed that the leveling and alignment of the teeth should be above the basal bone and leaded a new trend involving orthodontic treatment with tooth extraction against the previous idea ${ }^{20}$ of enlarging dental arches. Similar to the previous idea, in the 1990s, Dwight Damon developed the Damon system, which includes a passive selfligating bracket design and broader super elastic archwires, based on the thesis that low friction and light forces produce more biologically stable results. ${ }^{10}$ The Damon philosophy states that biologically friendly light forces expands posterior parts of dental arches and reduce the need for tooth extraction to dissolve crowding. ${ }^{11}$ When tooth extraction is inevitable, it is important to minimize the torque loss after incisor retraction. McLaughlin, Bennett, and Trevisi introduced the MBT prescription in 1997 and became very popular system among orthodontists. This prescription contained the following differences compared to others; greater palatal root inclination values at maxillary central incisor brackets (17 degrees), greater palatal root inclination values at maxillary lateral incisor brackets. (10 degrees), greater lingual crown inclination values at mandibular incisor brackets ( -6 degrees) and reduced tip values in the maxillary canine brackets (8 degrees). Researchers reported that the greater palatal root inclination values in the maxillary incisors improve the appearance of teeth with reduced torque values especially in cases with tooth extraction. ${ }^{21}$ In the literature, the effects of these two very popular prescriptions in treatments with and without extraction have not yet been compared. Therefore, the present study retrospectively evaluated pre- and post-treatment changes in cephalometric and dental model measurements between patients that were treated with an extraction approach using the conventional MBT bracket system and patients that were treated with a nonextraction approach using a self-ligating Damon bracket system.

An analysis of pretreatment measurements of both groups indicated that there are a number of factors taken into consideration when deciding whether to extract or retain premolar teeth, including soft tissue profile of the subject, the SNA (Sella-Nasion-point A angle) and SNB (SellaNasion-point B angle) angles that show the sagittal position of the maxilla and mandible with respect to the cranial base, and he SN-GoGn angle that is used to assess the vertical skeletal pattern. In the group that underwent four premolar extraction, the lips of the subjects were more protrusive and both the maxilla and mandible were located in more anterior positions when compared to the cranial base and also had a higher vertical angle while no significant differences were found between pretreatment inclinations of upper and lower incisors. Similarly, previous studies also indicated that the extraction of premolars and the retraction of the anterior segment in subjects with protrusive lips contribute to the improvement of lip profile through the retraction of lips. ${ }^{22,23}$ In contrast, Erdinc et al. ${ }^{24}$ showed significantly more protrusive and proclined incisors between extraction and nonextraction groups at the beginning of the study, while Basciftci et al. ${ }^{25}$ reported no significant differences in the positions of incisors were observed between the extraction and nonextraction Class I groups before treatment in agreement with our findings. The discrepancies in these outcomes may be related to the differences in inclusion criteria between studies.

In our study, no significant change was observed in cephalometric skeletal measurements in both groups, which could be attributed to the fact that the treatment remained at the dental level and the patients included in the study had not completed their growth and development. This finding was consistent with the findings reported by Başçiftçi and Üşümez ${ }^{25}$ and Başçiftçi et al. ${ }^{26}$ 
On the other hand, a significant increase was detected in the upper and lower incisor angles in the dental cephalometric measurements of the nonextraction group. This finding was consistent with the findings presented by previous studies reporting on the Damon bracket system. ${ }^{16,26-28}$ In the extraction group, however, the mandibular incisors retroclined significantly $(p<0.05)$ while no significant difference was observed in maxillary incisors $(p>0.05)$, which implicates that the anterior tooth size arch length discrepancies were eliminated by moderate anchorage and no effective upper incisor consolidation was performed to reduce dental angles. These findings were consistent with those reported by Finnoy et al. ${ }^{29}$ and Erdinç et al. ${ }^{24}$, while they contradicted those reported by Zierhut et al. ${ }^{30}$ and Başçiftçi et al. ${ }^{26}$ This contradiction could be attributed to the use of different space closure techniques at the beginning of the treatment in the extraction group and to the different levels of tooth size arch length discrepancies in the studies. On the other hand, both overjet and overbite did not change significantly in both groups. This finding could be ascribed to the treatment mechanics administered in both groups (implementation of moderate anchorage in the extraction group and the expansion of arches with the Damon Q bracket system). Although this finding was consistent with the findings presented by Atik and Ciğer ${ }^{27}$ who performed a nonextraction treatment with the Damon bracket system, it was inconsistent with the findings presented by Başçiftçi and Üşümez ${ }^{25}$ who found a significant reduction in overjet in Class I patients. This contradiction could be associated with the differences in subjects' pretreatment overjet values and the implementation of different treatment mechanics in the studies.

The treatment approaches performed in our study expectedly had different effects on the lip profiles of the subjects. In the nonextraction group, the lips moved significantly anteriorly due to the marked proclination of both the upper and lower teeth, which specifically led to a significant reduction in the upper lip thickness. In contrast, Başçiftçi et al. ${ }^{26}$ reported that only the lower lip significantly moved anteriorly in their patients. This difference could be related to the level of maxillary tooth size arch length discrepancies at the beginning of the treatment. Nevertheless, in our extraction group, both the lower and upper lips significantly moved posteriorly while no significant change was observed in lip thickness and angles.

In our study, the maxillary intercanine distance increased significantly in the group treated with an extraction approach using the conventional MBT bracket system. Meaningfully, an increase in the distance between the canines that are moved posteriorly following distalization with wide arches and arch forms is an expected outcome and this outcome was consistent with the findings presented by Aksu and Kocadereli ${ }^{1}$ and Kim and Gianelly ${ }^{20}$ In contrast, the maxillary and mandibular intermolar distances decreased significantly, which could be associated with the movement of these molars towards the mesial segment as a result of moderate anchorage. This finding was consistent with the findings presented by Kim and Gianelly ${ }^{20}$, while it was inconsistent with those presented by Aksu and Kocadereli. ${ }^{1}$ On the other hand, no significant change occurred in the mandibular intercanine distance despite the use of wide arches, which is highly important for the avoidance of post-treatment relapse. This finding contradicted the findings presented by Kim and Gianelly ${ }^{20}$ and Aksu and Kocadereli ${ }^{1}$, which could be attributed to the difference in the widths of arches used in the studies.

In the group treated with a nonextraction approach using the Damon bracket system, the interdental distance between all the maxillary and mandibular molars increased significantly. This finding confirmed the commonly known hypothesis that the Damon bracket system is useful for expanding the arches during the treatment and was consistent with the findings presented by Atik and $\mathrm{Ciğer}^{27}$, Vajaria et $a l^{28}$, and Başçiftçi et al. ${ }^{26}$ Nevertheless, the increase in mandibular intercanine distance can be alarming particularly for treatment stability. ${ }^{26}$

Although no significant difference was found between the two groups with regard to maxillary intercanine distance, both treatment approaches were found to provide similar outcomes with 
regard to maxillary intercanine distance through the use of wide arches.

Our study was limited since baseline skeletal and soft tissue measurements of both groups were significantly different from each other and only short-term effect of these treatments were evaluated in the study. Additionally, no evaluation was performed for the total duration of treatment for the patients. Further longitudinal studies are needed to provide a more robust comparison of changes induced by these treatment approaches by standardizing the cephalometric parameters and to investigate post-treatment relapse in the subjects. Moreover, further studies may involve different age groups and larger sample sizes and may compare these approaches with other techniques such as miniscrew-assisted treatment.

\section{CONCLUSIONS}

Both treatment methods provided significantly different outcomes with regard to cephalometric parameters except skeletal values, mentolabial angle and lower lip thickness and dental model parameters except overjet, overbite and maxillary intercanine distances. These two different treatment approaches showed opposite effects on the lips, mandibular incisor inclinations and intermolar widths. Accordingly, when selecting the treatment, these differences as well as the position of incisors, transversal dimensions of the dental arches and the lip profiles of the subjects should be taken into consideration.

\section{CONFLICTS OF INTEREST STATEMENT}

The authors declare that there is no competing interest.

\section{Çekimli ve Çekimsiz Ortodontik Tedavilerin Sefalometrik Yaptlar ve Ark Genişlikleri Üzerine Etkilerinin Karşılaştırılması}

\section{$\ddot{O} Z$}

Amaç: İki farklı tedavi yaklaşımının sefalometrik ölçümler ve ark genişlikleri üzerindeki etkilerini karşılaştırmaktır. Gereç ve Yöntemler: Sinıf I maloklüzyona sahip ve orta-şiddetli çapraşılkl̆ğ bulunan 45 bireyin sefalometrik radyografileri ve dental modelleri elde edilmiştir. Bireyler çekim yapılmayan (birinci) ve dört premolar çekimli (ikinci) olmak üzere iki gruba ayrılmıştır. Birinci grup, Damon $Q$ sistemi ile tedavi gören 22 hastadan (9 klz, 13 erkek ortalama yaş $18.0 \pm$ 1.68) oluşmakta iken ikinci grup konvansiyonel MBT braket sistemi ile tedavi edilen 23 hastadan (11 kız, 12 erkek yaş ortalaması: $17.9 \pm 1.34$ ) oluşmaktadır. Hastalarn tedavi öncesi ve sonrasi lateral sefalometrik radyografileri ve ark genişlikleri ölçülüp karşılaştırılmıştır. Her gruptaki tedavi değişikliklerini değerlendirmek için eşleştirilmiş örnekler t-testi kullanıldı. Gruplar arasındaki değişiklikleri karşılaştırmak için bağımsız örnekler t-testi yapıldı. Bulgular: Her iki grupta da tedavi ile sagital ve vertikal iskeletsel değerlerde istatistiksel olarak anlaml bir değişiklik görülmemiştir ( $p>0,05)$. Üst ve alt kesici dişlerde birinci grupta anlamlı proklinasyon gözlenirken $(p<0,01)$; ikinci grupta mandibular dişlerde anlaml $(p<0,05)$ retroklinasyon bulunmuştur. Dudakların birinci grupta belirgin olarak protrüze olduğu ve üst dudağın inceldiği gözlenmiş $(p<0,01)$, ancak ikinci grupta istatistiksel olarak anlamlı bir değişiklik gözlenmemiştir $(p>0,05)$. Birinci grupta tüm transvers dental model ölçümlerinde anlamlı $(p<0,01)$ artış tespit edilmiş, ancak ikinci grupta sadece intermolar genişliklerde anlamlı bir azalma gözlenmiştir $(p<0,01)$. Sonuç: İki tedavi yöntemi dental ve yumuşak dokular ile ark genişlikleri üzerine birbirine zit ve anlamll etkiler göstermiştir. Anahtar Kelimeler: Çekimli, çekimsiz, ortodonti.

\section{REFERENCES}

1. Aksu M, Kocadereli I. Arch width changes in extraction and nonextraction treatment in class I patients. Angle Orthod 2005;75:948-952.

2. Little RM, Wallen TR., Riedel RA. Stability and relapse of mandibular anterior alignment-first premolar extraction cases treated by traditional edgewise orthodontics. Am J Orthod 1981;80:349-365.

3. Bishara, SE, Cummins DM, Jakobsen JR. The morphologic basis for the extraction decision in Class II, division 1 malocclusions: a comparative study. Am J Orthod Dentofacial Orthop 1995;107:129-135.

4. Freitas KMS, Freitas DS, Valarelli FP, Freitas MR, Janson G. PAR evaluation of treated Class I extraction patients. Angle Orthod 2008;78:270-274.

5. Johnson DK, Smith RJ. Smile estheties after orthodontic treatment with and without extraction of four first premolars. Am J Orthod Dentofacial Orthop 1995;108:162-167.

6. Paquette DE, Beattie JR, Johnston Jr LE. A long-term comparison of nonextraction and premolar extraction 
edgewise therapy in "borderline" Class II patients. Am J Orthod Dentofacial Orthop 1992;102:1-14.

7. Weinberg M, Sadowsky C. Resolution of mandibular arch tooth size arch length discrepancies in growing patients with Class I malocclusions treated nonextraction. Am J Orthod Dentofacial Orthop 1996;110:359-364.

8. Fleming PS, DiBiase AT, Sarri G, Lee RT. Comparison of mandibular arch changes during alignment and leveling with 2 preadjusted edgewise appliances. Am J Orthod Dentofacial Orthop 2009;136:340-347.

9. Loh KW. Rapid tooth movement with a low-force, lowfriction bracket system. J Clin Orthod 2007;41:451-457.

10.DH D. Damon system, The Workbook. Sybron Dental 2004;14.

11. Tagawa D. The Damon system vs. conventional appliances: a comparative study. Clin Impressions 2006;15:4-9.

12. Damon D.The rationale, evolution and clinical application of the self-ligating bracket. Clinical orthodontics and research 1998;1:52-61.

13. Pandis N, Polychronopoulou A, Katsaros C, Eliades

T. Comparative assessment of conventional and selfligating appliances on the effect of mandibular intermolar distance in adolescent nonextraction patients: a single-center randomized controlled trial. Am J Orthod Dentofacial Orthop 2011;140:99-105.

14. Pandis N, Polychronopoulou A, Makou M, Eliades T. Mandibular dental arch changes associated with treatment of tooth size arch length discrepancies using self-ligating and conventional brackets. Eur J Orthod 2010;32:248-253.

15. Cattaneo PM, Treccani M, Carlsson K, Thorgeirsson T, Myrda A, Cevidanes LHS, B Melsen. Transversal maxillary dento-alveolar changes in patients treated with active and passive self-ligating brackets: a randomized clinical trial using CBCT-scans and digital models. Orthod Craniofac Res 2011;14:222-233.

16. Scott P, DiBiase AT, Sherriff M, Cobourne MT. Alignment efficiency of Damon3 self-ligating and conventional orthodontic bracket systems: a randomized clinical trial. Am J Orthod Dentofacial Orthop 2008;134: 470-470

17. Ileri Z, Basciftci FA, Malkoc S, Ramoglu SI. Comparison of the outcomes of the lower incisor extraction, premolar extraction and non-extraction treatments. Eur J Orthod 2012;34: 681-685.
18. Arman A, Toygar TU, Abuhijleh E. Profile changes associated with different orthopedic treatment approaches in Class III malocclusions. Angle Orthod 2004;74: 733-740.

19. Tweed $\mathrm{CH}$. The application of the principles of the edgewise arch in the treatment of class II, division 1, malocclusion. Angle Orthod 1936;6(3):198-208.

20. Kim E, Gianelly AA. Extraction vs nonextraction: arch widths and smile esthetics. Angle Orthod 2003;73:354-358.

21. McLaughlin RP, Bennett JC, Trevisi HJ. Systemized orthodontic treatment mechanics. Els Health Sci 2001.

22. Battagel JM. Profile changes in Class II, division 1 malocclusions: a comparison of the effects of Edgewise and Frankel appliance therapy. Eur J Orthod 1989;11:243-253.

23. Blanchette ME, Nanda RS, Currier GF, Ghosh J, Nanda SK. A longitudinal cephalometric study of the soft tissue profile of short-and long face syndromes from 7 to 17 years. Am J Orthod Dentofacial Orthop 1996;109:116-131.

24. Erdinc AE, Nanda RS, Dandajena TC. Profile changes of patients treated with and without premolar extractions. Am J Orthod Dentofacial Orthop 2007; 132:324-331.

25. Basciftci FA, Usumez S. Effects of extraction and nonextraction treatment on Class I and Class II subjects. Angle Orthod 2003;73:36-42.

26. Basciftci FA, Akin M, Ileri Z, Bayram S. Long-term stability of dentoalveolar, skeletal, and soft tissue changes after non-extraction treatment with a selfligating system. Korean J Orthod 2014;44:119-127.

27. Atik, E, Ciğer S. An assessment of conventional and self-ligating brackets in Class I maxillary constriction patients. Angle Orthod, 2014;84:615-622.

28. Vajaria R, BeGole E, Kusnoto B, Galang MT, Obrez. A Evaluation of incisor position and dental transverse dimensional changes using the Damon system. Angle Orthod 2011;81: 647-652.

29. Finnöy $J$, Wisth $P$, Böe $O$. Changes in soft tissue profile during and after orthodontic treatment. Eur $\mathbf{J}$ Orthod 1987;9:68-78.

30. Zierhut EC, Joondeph DR, Artun J, Little RM. Longterm profile changes associated with successfully treated extraction and nonextraction Class II Division 1 malocclusions. Angle Orthod 2000;70:208-219. 